\title{
Fish composition in the Guadiamar River basin after one of the worst mining spills in Europe
}

\author{
R. J. De Miguel ${ }^{1, *}$, F. J. Oliva-Paterna ${ }^{2}$, L. Gálvez-Bravo ${ }^{3}$ and C. Fernández-Delgado ${ }^{1}$ \\ ${ }^{1}$ Departamento de Zoología. Edificio Charles Darwin. Campus de Rabanales. Universidad de Córdoba. 14071 \\ Córdoba. Spain. \\ ${ }^{2}$ Departamento de Zoología y Antropología Física. Universidad de Murcia. 30100. Murcia. Spain. \\ ${ }^{3}$ Natural Sciences and Psychology, Liverpool John Moores University, James Parsons Building, Byrom Street, \\ Liverpool, L3 3AF, UK.
}

* Corresponding author: rjmiguel@uco.es

Received: 4/12/13

Accepted: 23/10/014

\begin{abstract}
Fish composition in the Guadiamar River basin after one of the worst mining spills in Europe

On 25 April 1998, the tailing pond of the Los Frailes mine in Aznalcollar (Seville, Spain) ruptured, causing one of the most harmful environmental disasters in Europe in recent decades. Through the crack, $6 \mathrm{hm}^{3}$ of acidic water and metallic mud were spilt, defaunating a large area of the Guadiamar River. After the spill cleanup and habitat restoration, multiple anthropogenic impacts continued to degrade the affected area. This work aimed to provide the most updated list of fish species in the Guadiamar River basin after the spill. Data were collected between 1999 and 2011 by electrofishing, light-traps, minnow-traps and multimesh gill-nests in 78 sampling sites. Species richness values for both native and exotic species in the Guadiamar River basin were high when compared with values for other right bank tributaries of the Guadalquivir River. This may be due to direct contact with the mouth of the Guadalquivir, which allowed the presence of migratory species. It may also be due to its location in the lower part of the Guadalquivir River basin, where exotic species accumulated. Among the Guadiamar River basin species, Luciobarbus sclateri and Squalius alburnoides have the widest distribution. The former is a generalist species resistant to unfavourable habitat changes, and the latter has a very successful breeding strategy. However, when focused on the affected area, there was a marked increase in exotic species, and both pumpkinseed (Lepomis gibbosus) and carp (Cyprinus carpio) co-dominated together with the native L. sclateri and S. alburnoides. The distribution of species within the river basin suggests that the upper section (except the Agrio reservoir) and middle section tributaries may be acting as native species shelters, while the affected area becomes an exotic species source. This information should be useful for monitoring future changes in the species composition and for management planning measures.
\end{abstract}

Key words: Guadiamar River, Aznalcollar, toxic spill, fish assemblage.

\section{RESUMEN}

Composición de la ictiofauna en la cuenca del Guadiamar tras uno de los vertidos mineros más importantes de Europa

El 25 de abril de 1998 se produjo la rotura de la balsa de estériles mineros asociada a la corta de Los Frailes en Aznalcóllar (Sevilla) propiedad de la empresa sueco-canadiense Boliden-Apirsa, produciéndose una de las mayores catástrofes ambientales de las últimas décadas en Europa. En este accidente se vertieron un total de $6 \mathrm{hm}^{3}$ de aguas acidas y lodos metálicos que provocaron la desaparición de la fauna acuática en el tramo afectado del río Guadiamar. A pesar de la restauración del hábitat realizada tras el vertido, aún son múltiples los impactos antrópicos que degradan el tramo afectado. Este trabajo pretende ofrecer la información más actualizada sobre la composición de especies de peces en la cuenca del Guadiamar tras el largo período trascurrido el vertido. Los datos fueron obtenidos entre 1999 y 2011 mediante pesca eléctrica, trampas de luz, minnow traps y redes de branquias o agalladeras en un total de 78 puntos de muestreo. Al comparar la composición de especies del Guadiamar con las otras cuencas de la margen derecha del Guadalquivir, los valores alcanzan máximos tanto para autóctonas como para exóticas. Esto es debido, por un lado, al contacto directo con la desembocadura del Guadalquivir que permite la presencia de individuos migradores y eurihalinos, y por otro, al estar localizada en la zona baja de la cuenca donde aumenta la presencia de especies exóticas. De entre los peces de la cuenca del Guadiamar, el barbo (Luciobarbus 
sclateri) y el calandino (Squalius alburnoides) son los mejores distribuidos, el primero es una especie generalista resistente a cambios extremos en el hábitat, y el segundo, posee una estrategia reproductiva muy exitosa. Sin embargo en el tramo afectado hay una notable presencia de especies exóticas, y tanto el Percasol (Lepomis gibbosus) como la carpa (Cyprinus carpio), se muestran codominantes. La distribución de las especies muestra finalmente como el tramo alto de la cuenca (excepto el embalse del Agrio) y los afluentes del tramo medio son un refugio de autóctonas, mientras el tramo afectado por el vertido se convierte en fuente de exóticas. Tal información debe servir por tanto para observar futuros cambios en la composición de especies y tomar medidas de gestión al respecto.

Palabras clave: Guadiamar, Aznalcóllar, vertido tóxico, comunidad de peces.

\section{INTRODUCTION}

The Iberian ichthyofauna includes only a few families, with a high degree of diversification at the species level and numerous endemisms. These endemisms are approximately $80 \%$ of the Iberian species and belong to the Cyprinidae, Cobitidae and Cyprinodontidae families, showing the highest proportion of endemic fish species in Europe (Doadrio, 2001; Kottelat \& Freyhof, 2007). As in other Mediterranean peninsulas, the complex orography isolated many independent river systems from other European regions, where the different species' populations tended towards speciation (Clavero et al., 2004). Southern Iberian basins endure long droughts and abrupt floods, common in the Mediterranean climate (Gasith \& Resh, 1999). This variability is the key determinant of the structure of fish assemblages (Magalhâes et al., 2002), with a special relevance to the position of each river stretch within the river basin network (Filipe et al., 2002). The extreme dry conditions in summer cause a significant loss in habitat and connectivity (Matthews \& Marsh-Matthews, 2003) and in several cases, large decreases in fish populations. In addition to this, water extraction by humans increases in this season, especially in areas with agricultural and tourism land uses (Clavero \& Hermoso, 2011). These anthropogenic pressures are often related to habitat degradation or destruction through pollution, flow regulation (reservoirs, channels, etc.), land use changes and exotic species introductions. The sum of these effects is causing a progressive decay of fish populations in the Iberian drainages (Ribeiro et al., 2008).

Nevertheless, the above pressures can be exceeded by a pulse disturbance, such as a large toxic spill. One of the most damaging discharges in Europe occurred in the Guadiamar River basin, south-western Iberian Peninsula. On 25 April 1998, $6 \mathrm{hm}^{3}$ of metallic sludge and acid water were released from a tailing pond of the Los Frailes mine owned by the Swedish-Canadian company Boliden-Apirsa in the province of Seville, Spain (Aguilar et al., 2003). The spill defaunated the Agrio River and $60 \mathrm{~km}$ of the Guadiamar River (Grimalt \& Macpherson, 1999). According to estimates, more than $35 \mathrm{t}$ of dead fish were collected from the affected area (Valls \& Blasco, 2005). Shortly after the spill, mud removal commenced and a recovery plan consisting of chemical stabilisation, bank restoration and reforestation was undertaken, not only to repair the damaged ecosystems but also to transform the affected area into a green corridor between two well conserved areas: Sierra Morena in the north and Doñana National Park in the south (Arenas et al., 2008). Most of the major effects related to the spill were mitigated with the above mentioned recovery works. However, mining leachates, insufficiently treated sewage, industrial spills, agricultural diffuse pollution, water extractions and numerous watercourse obstacles present in the watershed before the accident have not yet been alleviated (De Miguel, 2013). Given the strong influence of other anthropogenic pressures that were acting on the Guadiamar basin 
before 1998, it is likely that the fish assemblages affected by the spill were already deteriorated with respect to their original state. Thus, the current fish assemblage is likely the result of both pulse and press disturbances (Lake, 2000) acting together.
Despite this outstanding aquatic defaunation event, no information has been published in international journals about the fish assemblage composition in the affected area of the Guadiamar River after the spill. Only De Miguel et al. (2013) addressed the mid-term effect of the spill on fish

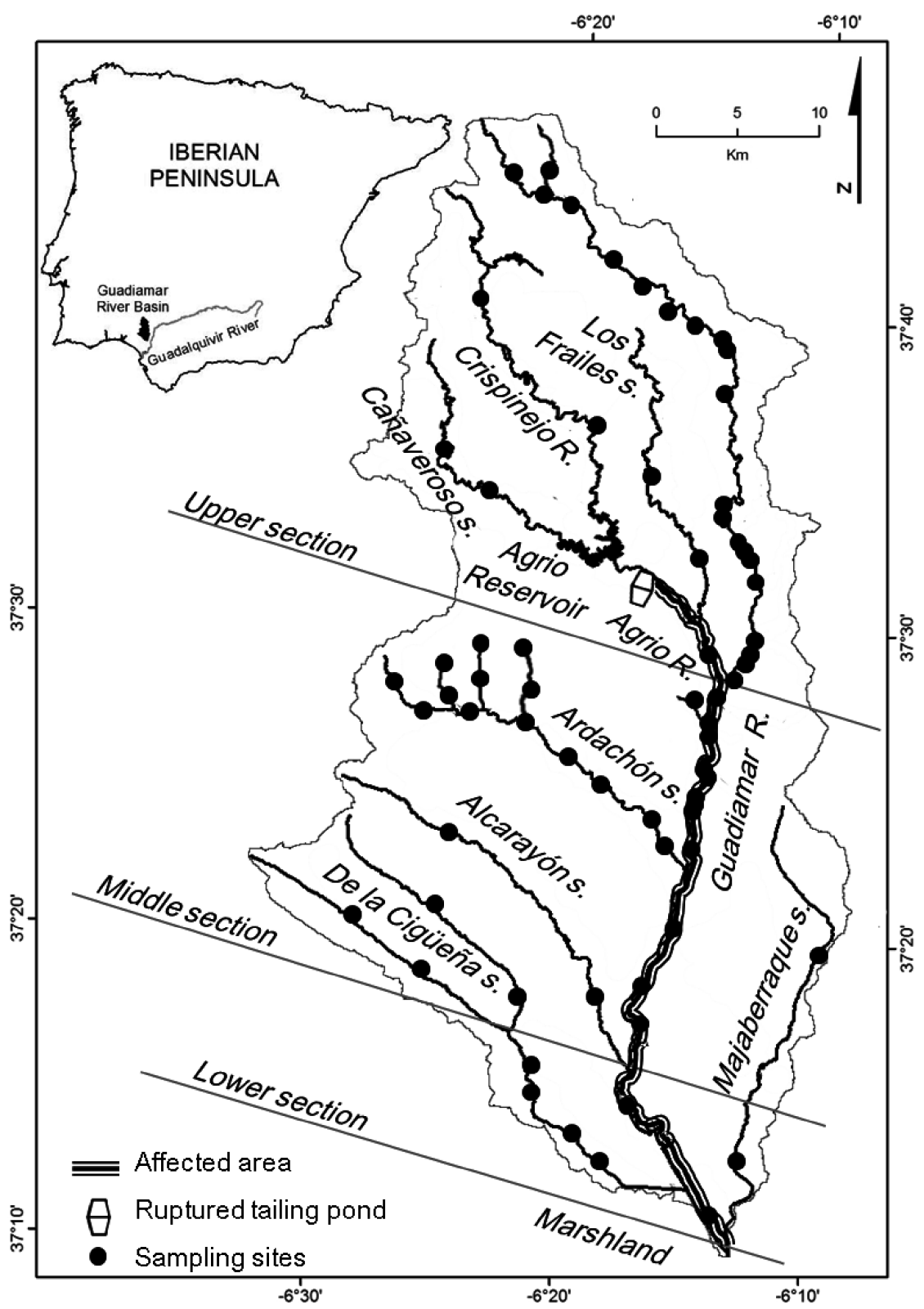

Figure 1. Location of the Guadiamar River basin, different sections, river network, the area affected by the spill and sampling sites are shown. Localización de la cuenca del Guadiamar donde se muestran los diferentes tramos, la red fluvial, el área afectada por el vertido y los puntos de muestreo. 
but focused on one species (Luciobarbus sclateri). Accordingly, knowledge of the current status of the fish assemblages should receive more attention. The purpose of this study was to provide an updated list of the Guadiamar River basin fishes, focusing on the species composition and their frequency of occurrence, which can be used as a reference document for future studies.

\section{MATERIAL AND METHODS}

\section{Study area}

The Guadiamar River basin drains an area of $1880 \mathrm{~km}^{2}$ in the South-western Iberian Peninsula near the Guadalquivir River mouth (Fig. 1). The climate is sub-humid Mediterranean with oceanic influences and average temperatures range from
$9{ }^{\circ} \mathrm{C}$ in winter to $29^{\circ} \mathrm{C}$ in summer. Climatic seasonality results in an irregular hydrological regime on both intra- and inter-annual scales, with an alternation of summer droughts and flash floods during rainy periods. The severe droughts cause the drying of most small streams and the isolation of pools during summer (Gasith \& Resh 1999). The Guadiamar River basin shows land use changes linked to river section type along the longitudinal gradient. Pine forests (Pinus spp.) and dehesas (Quercus spp., xeric Mediterranean forest) are the predominant vegetation in the upper section. Olive groves, cereal fields and vineyards form a mosaic in the middle section. In the lower section of the basin, close to the Doñana Natural Park, there is a marsh area dominated by Salicornia spp. shrubs and pastures with Sylibus marianum, Hordeum murinum and Plantago coronopus. The hydrological network

Table 1. List of taxa collected from 78 sampling sites in the Guadiamar River basin where new records detected for the basin (*), the Iberian status for each taxa (native vs. exotic) and the conservation status according to IUCN are shown. (1) Denomination of the species in accordance to the Kottelat \& Freyhof (2007) information. (L) In addition to adults, larval stage has been detected in the main watercourse. Lista de taxones presentes en los 78 puntos de muestreo establecidos por la cuenca del Guadiamar donde se muestran las nuevas presencias detectadas para la cuenca (*), el estatus del taxón (autóctono vs. alóctono) para la Península Ibérica y el estado de conservación según la UICN están indicados. (1) Denominación de la especie de acuerdo con la información de Kottelat y Freyhof (2007). (L) Además de adultos, se ha detectado estadio larvario para la especie en el cauce principal.

Taxonomic list

\begin{tabular}{|c|c|}
\hline Anguillidae & Anguilla anguilla Linnaeus, 1758 \\
\hline Atherinidae & Atherina boyeri Risso, $1810^{(L)}$ \\
\hline Cobitidae & Cobitis paludica (de Buen, 1930) $)^{(L)}$ \\
\hline \multirow[t]{8}{*}{ Cyprinidae } & Alburnus alburnus (Linnaeus, 1758)* \\
\hline & Carassius gibelio (Bloch, 1782)*(1) \\
\hline & Cyprinus carpio Linnaeus, $1758^{(L)}$ \\
\hline & Pseudochondrostoma willkommii (Steindach \\
\hline & Iberochondrostoma lemmingii (Steindachne \\
\hline & Luciobarbus sclateri (Günther, 1868) $)^{(L)}$ \\
\hline & Squalius alburnoides (Steindachner, 1866) c \\
\hline & Squalius pyrenaicus (Günther, 1868) \\
\hline Poeciliidae & Gambusia holbrooki Girard, 1859* \\
\hline \multirow[t]{2}{*}{ Centrarchidae } & Lepomis gibbosus (Linnaeus, 1758) $)^{(L)}$ \\
\hline & Micropterus salmoides (Lacepède, 1802) ${ }^{(L)}$ \\
\hline Ictaluridae & Ameiurus melas (Rafinesque, 1820)* \\
\hline \multirow[t]{2}{*}{ Mugilidae } & Liza ramada (Risso, 1827) \\
\hline & Mugil cephalus Linnaeus, 1758 \\
\hline
\end{tabular}

Iberian status Conservation status (IUCN 2013)

$\begin{array}{lc}\text { native } & \mathrm{CR} \\ \text { native } & \mathrm{LC} \\ \text { native } & \mathrm{VU} \\ \text { exotic } & - \\ \text { exotic } & - \\ \text { exotic } & - \\ \text { native } & \mathrm{VU} \\ \text { native } & \mathrm{VU} \\ \text { native } & \mathrm{LC} \\ \text { native } & \mathrm{VU} \\ \text { native } & \mathrm{NE} \\ \text { exotic } & - \\ \text { exotic } & - \\ \text { exotic } & - \\ \text { exotic } & - \\ \text { native } & \mathrm{LC} \\ \text { native } & \mathrm{LC}\end{array}$


is interrupted by three dams (Fig. 1). Two of the dams collect less than $4 \mathrm{hm}^{3}$ in the source area of the Crispinejo River, and there is one large reservoir $\left(20 \mathrm{hm}^{3}\right)$ in the Agrio River, slightly upstream from the spill point (Borja et al., 2001).

\section{Data sources and sampling protocols}

The analysis of Guadiamar River basin fish composition was part of a wider study that assessed the long-term effects caused by the spill on fish communities. This monitoring focused on the affected area (4286 ha; Aguilar et al., 2003), which covered both the fluvial sector and marshland. Fish captures were part of several projects carried out between 1999 and 2011 (intensive campaigns in 2002-2004, 2006-2007 and 2011). Data on fish communities from the Guadiamar River basin that were available in the literature were also included.

A total of 78 sampling sites located on the fluvial sector of the watershed were surveyed. Although the sampling effort in the main watercourse was higher, the permanent streams were split into hydrological fragments in order to conduct a representative sampling of the whole network. The minimum stretch covered at each sampling site was approximately $100 \mathrm{~m}$ long. An attempt was made to sample all of the different habitats within the stretches to detect the complete species richness at a given sampling site. Fish were collected using different sampling methods depending on the site characteristics: (1) electrofishing following the European Committee for Standardization (CEN) standard protocol (CEN, 2003) in 58 sites; (2) sampling of fish larvae (only in 2003 and 2004) using light traps similar to those described in Floyds et al. (1984; in Pérez-Alejandre, 2009) in 15 sites; (3) passive sampling using minnow-traps (Harrison et al., 1986; $0.5 \mathrm{~m}$ length, $0.03 \mathrm{~m}$ diameter entrance) left for 22-24 hours in 5 sites; and (4) sampling with multi-mesh gillnets $(30 \mathrm{~m}$ long and $1.5 \mathrm{~m}$ deep) placed transversely from the edges in deep zones, with a soaking time longer than 12 hours in the same previous 5 sites.

Most specimens were identified in situ to species level and released thereafter. Young- of-the-year and larvae were identified in the laboratory (Fernández-Delgado et al., 2000). Some individuals of each species were preserved and deposited in the ichthyological collection of the Department of Zoology of the University of Cordoba (Spain).

\section{RESULTS AND DISCUSSION}

The fluvial systems of the Guadiamar River basin (marshland not included) hosted a typical Iberian low-diversity fish assemblage composed of 17 species (10 natives and 7 exotics) representing 8 families (Table 1). Cyprinidae were the most diverse family, followed by Centrarchidae and Mugilidae. Five of the native fish species $(29.4 \%)$ caught are listed in the IUCN red list under threatened species (Table 1). The seven exotic species $(41.2 \%)$ were among the most harmful invasive fish species for aquatic ecosystems in the Iberian Peninsula (Ribeiro et al., 2008; Doadrio et al., 2011; Ribeiro \& Leunda, 2012).

Four exotic species listed in this study ( $\mathrm{Al}$ burnus alburnus, Carassius gibelio, Gambusia holbrooki and Ameiurus melas) were not present in the fish assemblage that was described by Doadrio (2001) before the spill. Nevertheless, the present taxonomic list (Table 1) was similar to the current species composition detected in nearby watersheds from the South-Western Iberian Peninsula (De Miguel et al., 2010; Fernández-Delgado et al., 2014). Carassius gibelio was assumed to be the captured Carassius spp. Individuals, because instead of $C$. auratus (and according to Kottelat \& Freyhof 2007), the former is a recent occurrence throughout Europe related to the introduction of Cyprinus carpio in reservoirs. In addition, recent genetic analyses confirmed the presence of $C$. gibelio in the Guadalquivir River basin (Kalous et al., 2012; L. Kalous personal communication).

When Guadiamar River basin species richness was compared with that of the other right bank tributaries from the Guadalquivir River, the Guadiamar River reached the maximum value (17 species; Table 2). These right bank tributaries from the Guadalquivir River had similar 
drainage areas and environmental conditions (climate, geology, geomorphology, hydrology and vegetation) to the Guadiamar River basin. However, both the Guadiamar River and Rivera de Huelva River mouths are located downstream from the first large dam in the Guadalquivir River main stem, which has allowed the entrance of migratory and euryhaline species from the estuary (Anguilla anguilla, Atherina boyeri, Mugil cephalus and Liza ramada) but interrupted access for the rest of upstream right bank tributaries. Another reason for the high species richness with respect to the other neighbouring basins may be the accumulation of exotic species in the lower section of large Iberian drainages. This distribution pattern occurs because reservoirs are the source of most exotic fish species introduced in the Iberian Peninsula (Ribeiro \& Leunda, 2012). Therefore, fish are asymmetrically spread and found mostly downstream from reservoirs, where flow is continuous, rather than upstream, where introduced fish are not adapted to the unstable stream conditions (Ribeiro et al., 2008).

Generally, fish assemblages in Mediterranean rivers are dominated by just a few tolerant species that are widely distributed, accompanied by other species with a reduced distribution, associated to particular habitats and with limited expansion potential (Encina et al., 2006). According to the frequency of occurrence (FO) of each fish species in all of the sampling sites within the Guadiamar River basin, Luciobarbus sclateri $(\mathrm{FO}=64.5 \%)$ and Squalius alburnoides $(\mathrm{FO}=$ $50.0 \%$ ) were the dominant fish species (Table 3). The former is a generalist species (Encina \& Granado-Lorencio, 1997) widely adapted to unfavourable conditions (Doadrio et al., 2011). This makes L. sclateri the most ubiquitous and abundant species in the southern Iberian river courses (Oliva-Paterna et al., 2003; Fernández-Delgado et al., 2014). On the contrary, S. alburnoides avoids watercourses where anthropogenic pollution and sediment accumulation have a strong influence (Fernández-Delgado et al., 2014). Nevertheless, advantageous hybridisation reproductive modes (Carmona et al., 1997, Alves et al., 1998), promotes its large populations and widespread distribution throughout watercourses, where the degree of degradation is acceptable for the species (Fernández-Delgado et al., 2014).

However, focusing on the sampling sites within the affected area, the FO changed, es-

Table 2. List of right bank tributaries from the Guadalquivir River, drainage basin $\left(\mathrm{Km}^{2}\right)$ and species richness according to Fernández-Delgado et al., (2014). Roman numbers indicate connection order to the Guadalquivir River, (I) nearest tributary to the source and (XII) nearest to the mouth. Área de drenaje $\left(\mathrm{Km}^{2}\right)$ y composición de especies de los tributarios de la margen derecha del Guadalquivir según Fernández-Delgado et al., (2014). Los números romanos indican el orden de unión del tributario al Guadalquivir, (I) el tributario más cercano al nacimiento y (XII) el más cercano a la desembocadura.

\begin{tabular}{lcccc}
\hline Tributary & Área $\left(\mathrm{Km}^{2}\right)$ & Native spp. & Exotic spp. & Richness \\
\hline Guadalimar (I) & 5241 & 7 & 5 & 12 \\
Rumblar (II) & 712 & 5 & 3 & 8 \\
Jándula (III) & 2570 & 5 & 4 & 9 \\
Yeguas (IV) & 2570 & 5 & 4 & 9 \\
Guadalmellato (V) & 1288 & 5 & 2 & 7 \\
Guadiato (VI) & 1491 & 6 & 3 & 9 \\
Bembezar (VII) & 1993 & 7 & 2 & 9 \\
Retortillo (VIII) & 358 & 6 & 3 & 9 \\
Rivera de Hueznar (IX) & 683 & 6 & 3 & 9 \\
Viar (X) & 1784 & 7 & 2 & 17 \\
Rivera de Huelva (XI) & 1979 & 10 & 7 & 17 \\
Guadiamar (XII) & 1325 & 10 & 7 & \\
\hline
\end{tabular}


pecially for exotic species. Lepomis gibossus and $C$. carpio significantly increased their FO (when compared to all of the sampling sites) to $75.0 \%$ and $65.0 \%$, respectively, and the remaining exotic species increased on average to $30 \%$ in this stretch. Both native and exotic fish larvae were caught in the affected area (Table 1), supporting the local reproductive activity and the presence of a consolidated fish assemblage (Pérez-Alejandre, 2009).

There is a general lack of exotic fish species in the upper section of the basin (except the Agrio reservoir) and in the upper reaches of the Guadiamar River tributaries. However, downstream from the Agrio reservoir and the Aznalcóllar mines (the middle and lower section of the Guadiamar River connected with the Doñana marshland) the FO of exotic species is the highest, so they may be considered as exotic fish species sources (Table 3 ).

In summary, more than a decade after the accident, the Guadiamar River fish assemblage is substantially different from that which could be considered as recovered (Doadrio, 2001). When compared to the pre-spill fish assemblage (Doadrio, 1996; CEDEX, 1997), there was a depletion in the native species and an increase in exotics in the affected reach. Quantitative information on abundance, population dynamics and fish species trends are needed in order to obtain the appropriate evaluations of the factors responsible for its current status. The present study may serve as a comparative species richness account against which future fish assemblage shifts may be evaluated.

\section{ACKNOWLEDGMENTS}

Data presented in this study were collected under different projects funded by the Consejería de Medio Ambiente de la Junta de Andalucía and the Confederación Hidrográfica del Guadalquivir (Spain). We thank T. Saldaña, P. Guarnizo, D.

Table 3. Taxa recorded in the Guadiamar River basin, with locations within the river basin including main stem pre-spill distribution according to Doadrio (1996) and CEDEX (1997), and tributaries and frequency of occurrence (FO\%) at the 78 sampling sites. Registro actual de taxones para la cuenca del Guadiamar, indicando las especies presentes con anterioridad al vertido en el cauce principal del Guadiamar según Doadrio (1996) y CEDEX (1997), y el rango de distribución y la frecuencia de ocurrencia (FO\%) obtenida para los 78 puntos de muestreo.

\begin{tabular}{|c|c|c|c|}
\hline Species & Pre-spill & Main stem sector and tributaries & $\mathrm{FO}(\%)$ \\
\hline \multicolumn{4}{|l|}{ Natives } \\
\hline Anguilla anguilla & Gup & Gup,Gmid,Glow,AR & 11.5 \\
\hline Atherina boyeri & & Gmid & $<2.5$ \\
\hline Cobitis paludica & Gup & Gup,Gmid,Glow,LF,CA,AL & 37.2 \\
\hline Pseudochondrostoma willkommii & Gup,Gmid & Gup,Gmid,LF,CA & 39.7 \\
\hline Iberochondrostoma lemmingii & Gup,Gmid & Gup,Gmid, LF & 6.4 \\
\hline Luciobarbus sclateri & Gup,Gmid & Gup,Gmid,Glow,LF,CA,RC,AR,DC,AG & 64.5 \\
\hline Squalius alburnoides complex & Gup,Gmid & Gup,Gmid,LF,CA,AR & 50.0 \\
\hline Squalius pyrenaicus & Gup & Gup,Gmid,LF,CA,AR & 21.8 \\
\hline Liza ramada & & Gmid,Glow & 3.8 \\
\hline Mugil cephalus & & Gmid,Glow & 5.1 \\
\hline \multicolumn{4}{|l|}{ Exotics } \\
\hline Alburnus alburnus & & Gmid, Glow,AR,DC & 13.5 \\
\hline Carassius gibelio & & Gmid,Glow,AG & 10.2 \\
\hline Cyprinus carpio & Gmid & Gmid,Glow & 23.1 \\
\hline Gambusia holbrooki & & Gup,Gmid,Glow,LF,AR,MA & 19.2 \\
\hline Lepomis gibbosus & Gmid & Gup,Gmid,Glow, AR,AG & 28.2 \\
\hline Micropterus salmoides & Gup & Gup,Gmid,LF & 14.1 \\
\hline Ameiurus melas & & Gup & $<2.5$ \\
\hline
\end{tabular}

(Gup, Gmid and Glow: upper, middle and lower Guadiamar River main stem; AR: Ardachón; LF: Los Frailes; CA: Cañaveroso; RC: Crispinejo; AL: Alcarayón; AG: Agrio; MA: Majaberraque; DC: De La Cigüeña). 
García, C. García, A. Fernández, C. Arribas, J. Berná, R. Pérez, A. Barranco, D. Redondo, M. Fernández, E. Pino, A. Ramiro, J. Peña, F. Aranda and R. Moreno for their help both in the field and with GIS.

\section{REFERENCES}

AGUILAR, J., R. BELLVER, C. DORRONSORO, E. FERNÁNDEZ, J. FERNÁNDEZ, I. GARCÍA, A. IRIARTE, F. MARTÍN, I. ORTIZ \& M. SIMÓN. 2003. Contaminación de los suelos tras el vertido tóxico de Aznalcóllar. Editorial Universidad de Granada y Consejería de Medio Ambiente (Junta de Andalucía), Sevilla, Spain.

ALVES, M. J., M. M. COELHO \& M. J. COLLARES-PEREIRA. 1998. Diversity in the reproductive modes of females of Rutilus alburnoides complex (Teleostei, Cyprinidae): a way to avoid the genetic constaints of uniparentalism. Molecular Biology and Evolution, 5(10): 1233-1242.

ARENAS, J. M., F. CARRASCAL, A. GIL \& C. MONTES. 2008. Breve historia de la construcción del Corredor Verde del Guadiamar. In: $L a$ restauración ecológica del río Guadiamar y el proyecto del Corredor Verde. Junta de Andalucía (ed.): 263-281. Sevilla, Spain.

BORJA, F., J. A. LÓPEZ-GETA, M. MARTÍN-MACHUCA, R. MANTECÓN, C. MEDIAVILLA, P. DEL OLMO, M. PALANCAR \& R. VIVES. 2001. Marco geográfico, geológico e hidrológico regional de la Cuenca del Guadiamar. Boletín Geológico y Minero, 112: 13-34.

CARMONA, J. A., O. I. SANJUR, I. DOADRIO, A. MACHORDOM \& R. C. VRIJENHOEK. 1997. Hybridogenetic Reproduction and Maternal Ancestry of Polyploid Iberian Fish the Tropidophoxinellus alburnoides Complex. Genetics, 146: $983-$ 993.

CEDEX. 1997. Catalogación y criterios de conservación de los peces e inventario de la vegetación de ribera de siete tramos fluviales de la cuenca del Guadalquivir. Río Guadiamar. CEDEX, University of Seville, Spain.

CEN. 2003. Water quality. Sampling of fish with electricity. EN 14011. European Committee for Standardization, Brussels, Belgium.

CLAVERO, M., F. BLANCO-GARRIDO \& J. PRENDA. 2004. Fish fauna in Iberia Mediterranean river basins biodiversity, introduced species and damming impacts. Aquatic Conservation: $M a-$ rine and Freshwater Ecosystem, 14: 575-585.

CLAVERO, M. \& V. HERMOSO. 2011. Reservoirs promote the taxonomic homogenization of fish communities within river basins. Biodiversity and Conservation, 20:41-57.

DE MIGUEL, R. J., E. PINO, A. RAMIRO, F. ARANDA, J. P. PEÑA, I. DOADRIO \& C. FERNÁNDEZ-DELGADO. 2010. On the occurrence of Anaecypris hispanica, an extremely endangered Iberian endemism, in the Guadalquivir River basin. Journal of Fish Biology, 76: 1454-1465.

DE MIGUEL, R. J. 2013. Las comunidades de peces del río Guadiamar y el accidente minero de Aznalcóllar. Ph. D. Thesis. University of Cordoba, Spain.

DE MIGUEL, R. J., F. J. OLIVA-PATERNA, L. GÁLVEZ-BRAVO \& C. FERNÁNDEZ-DELGADO. 2013. Habitat quality affects the condition of Luciobarbus sclateri in the Guadiamar River (SW Iberian Peninsula): Effects of disturbances by the toxic spill of the Aznalcóllar mine. Hydrobiologia, 700: 85-97.

DOADRIO, I. 1996. Estudio sobre la calidad de las aguas continentales destinadas a la vida piscícola en el ámbito de la cuenca del Guadalquivir. INIMA. Ministerio de Medio Ambiente, Madrid, Spain.

DOADRIO, I. (ed.). 2001. Atlas y Libro Rojo de los Peces Continentales de España. Dirección General de Conservación de la Naturaleza. Madrid, Spain.

DOADRIO, I., S. PEREA, P. GARZÓN-HEYDT \& J. L. GONZÁLEZ. 2011. Ictiofauna continental española. Bases para su seguimiento. DG Medio Natural y Política Forestal. MARM. Madrid, Spain.

ENCINA, L. \& C. GRANADO-LORENCIO. 1997. Food habits and food resource partitioning in three coexisting Barbus species. Folia Zoologica, 46: 325-336.

ENCINA, L., A. RODRÍGUEZ-RUIZ \& C. GRANADO-LORENCIO. 2006. The Iberian ichthyofauna: Ecological contributions. Limnetica, 25(1-2): 349-368.

FERNÁNDEZ-DELGADO, C., P. DRAKE, A. M. ARIAS \& D. GARCÍA. 2000. Peces de Doñana y su entorno. Organismo Autónomo Parques Nacionales. Environment Ministry Publishers. Madrid, Spain.

FERNÁNDEZ-DELGADO, C., OLIVA-PATERNA, F. J., RINCÓN P. A., GÁLVEZ-BRAVO, L., 
DE MIGUEL, R. J., E. PINO, A. RAMIRO, F. ARANDA \& J. P. PEÑA. 2014. Distribución y estado de conservación de los peces dulceacuícolas del río Guadalquivir. Principales áreas fluviales para su conservación. Ministerio de Agricultura, Alimentación y Medio Ambiente. Confederación Hidrográfica del Guadalquivir. Sevilla, Spain.

FILIPE, A. F., I. G. COWX \& M. J. COLLARESPEREIRA. 2002. Spatial modelling of freshwater fish in semi-arid river systems: a tool for conservation. River Research and Applications, 18: 123136.

GASITH, A. \& V. H. RESH. 1999. Streams in Mediterranean climate regions: abiotic in?uences and biotic responses to predictable seasonal events. Annual Review of Ecology and Systematics, 30: 51-81.

GRIMALT, J. O. \& E. MACPHERSON. 1999. The environmental impact of the mine tailing accident in Aznalcóllar (South-west Spain). The Science of the Total Environment, 242(1-3): 1-337.

HARRISON, T. D., A. E. L. RAMM \& E. C. CERFF. 1986. A low-cost effective trap for use in sampling aquatic fauna. Aquaculture, 58: 145-149.

IUCN. 2013. 2013 IUCN Red List of Threatened Species. The IUCN Species Survival Commission. http://www.redlist.org. Accessed 17 October 2013.

KALOUS, L., J. BOHLEN, K. RYLKOVÁ \& M. PETRTÝL. 2012. Hidden diversity within the Prussian carp and designation of a neotype for Carassius gibelio (Teleostei: Cyprinidae). Ichthyological Exploration of Freshwaters, 23(1): 11.

KOTTELAT, M. \& J. FREYHOF. 2007. Handbook of European Freshwater Fishes. Kottelat, Cornol, Switzerland and Freyhof, Berlin, Germany.
LAKE, P. S. 2000. Disturbance, patchiness, and diversity in streams. Journal of the North American Benthological Society, 19(4): 573-592.

MAGALHÂES, M. F., P. BEJA, C. CANAS \& M. J. COLLARES-PEREIRA. 2002. Functional heterogeneity of dry-season fish refugia across a Mediterranean catchment: the role of habitat and predation. Freshwater Biology, 47: 1919-1934.

MATTHEWS, W. J. \& E. MARSH-MATTHEWS. 2003. Effects of drought on fish across axes of space, time and ecological complexity. Freshwater Biology, 48: 1232-1253.

OLIVA-PATERNA, F. J., A. VILA-GISPERT \& M. TORRALVA. 2003. Condition of Barbus sclateri from semi-arid aquatic systems: effects of habitat quality disturbances. Journal of Fish Biology, 23: 699-709.

PÉREZ-ALEJANDRE, R. 2009. Biología y ecología de las larvas de peces del río Guadiamar en zonas afectadas y no afectadas por el vertido tóxico de las monas de Áznalcollar. Ph. D. Thesis. University of Cordoba, Spain.

RIBEIRO, F., B. ELVIRA, M. J. COLLARESPEREIRA \& P. B. MOYLE. 2008. Life-history traits of non-native fishes in Iberian watersheds across several invasion stages: a first approach. Biological Invasions, 10: 89-102.

RIBEIRO, F. \& P. M. LEUNDA. 2012. Non-native fish impacts on Mediterranean freshwater ecosystems: current knowledge and research needs. Fisheries Management and Ecology, 19(2): 142-156.

VALLS, A. \& J. BLASCO. 2005. Integrated assessment and management of the ecosystems affected by the Aznalcóllar mining spill (SW, Spain). UNESCO Unitwin. Cádiz, Spain. 